\title{
ISOLASI DAN IDENTIFIKASI SENYAWA KIMIA DARI EKSTRAK ETIL ASETAT DAUN SIRSAK DAN UJI BAKTERI STREPTOCOCCUS MUTANS ATCC 31987
}

\author{
${ }^{1}$ Irvan Herdiana, ${ }^{2}$ Siswa Setyahadi, \& ${ }^{3}$ Partomuan S. \\ ${ }^{1}$ Jurusan Farmasi Poltekkes Kemenkes Tasikmalaya, \\ ${ }^{2}$ Pusat Penelitian IImu Pengetahuan dan Teknologi, Serpong, Tanggerang. \\ ${ }^{3}$ Pusat Penelitian Bioteknologi, LIPI Cibinong
}

\begin{abstract}
Abstrak
Berbagai obat antibiotik telah banyak digunakan secara klinis untuk pengobatan infeksi yang disebabkan oleh bakteri gram positif maupun gram negatif. Namun obat antibiotik tersebut memiliki sejumlah efek samping, baik ringan maupun berat. Bakteri Streptococcus mutans adalah bakteri penyebab utama dalam pembentukan karies gigi. Bermanfaat sebagai pengobatan infeksi. Tujuan penelitian ini adalah untuk mengetahui senyawa dari fraksi etil asetat daun sirsak yang berperan sebagai antibakteri dalam menghambat pertumbuhan bakteri Streptococcus mutans ATCC 31987. Studi aktivitas penghambatan pertumbuhan bakteri dilakukan secara invitro dengan metode diameter daya hambat dengan mengukur diameter zona bening di sekitar disk pada media padat yang ditumbuhi bakteri menggunakan jangka sorong. Hasil penelitian menunjukkan bahwa fraksi etil asetat daun tumbuhan sirsak dari isolat Sub Fraksi F.7.IV memiliki aktivitas antibakteri melalui daya hambat pertumbuhan bakteri Streptococcus mutans ATCC 31987 pada konsentrasi 40\%, 20\%, 10\% dan 5\% dengan kategori tidak aktif, Analisis data dan identifikasi senyawa dilakukan dengan LCMS dan FT-IR, terdapat campuran 3 senyawa yaitu; annopentocin C, annopentocin B dan annomuricin D-one.
\end{abstract}

Kata kunci: Antibakteri, Streptococcus mutans, Annona muricata, Annopentocin C.

\begin{abstract}
Various antibiotic agents have been widely used clinically both Gram positif and Gram negative infection. Eventough those agent had a number of side effects ranging from mild to serious. Streptococcus mutans known as main cariogenic agent. Which empirically used as antibacteria as well. The purpose of this study was to determine the compound of ethyl acetate fraction of soursop leaf that can be used against Streptococcus mutans activity. Invitro study are performed with difussion method to measure the inhibition zone. The results showed that ethyl acetate fraction of the soursop leaf (Annona muricata) from Fr.F.7.IV islotate has lowactivity with concentration $40 \%, 20 \%, 10 \%$ dan 5\% through Streptococcus mutans ATCC 31987. LCMS and FT-IR were performed to identify 3 chemical compound of fractions and showed the presence of annopentocin $C$, annopentocin $B$ and annomuricin $D$ one.
\end{abstract}

Keywords: Antibacteria, Streptococcus mutans, Annona muricata, Annopentocin.

\section{PENDAHULAN}

Metode uji aktivitas bakteri merupakan metode untuk mengetahui dan mendapatkan produk yang berpotensi sebagai bahan anti bakteri serta mempunyai kemampuan untuk menghambat pertumbuhan atau mematikan bakteri pada konsentrasi yang rendah, salah satunya yaitu dari bahan alam. Mekanisme kerja dari senyawa antibakteri diantaranya yaitu menghambat sintesis dinding sel, menghambat keutuhan permeabilitas dinding sel bakteri, menghambat kerja enzim, dan menghambat sintesis asam nukleat dan protein (Jawetz, Melnick, \& Adelberg, 2005). 
Penggunaan sirsak sebagai obatobatan bukan merupakan suatu hal yang baru di Indonesia. Secara turun temurun, sirsak telah digunakan oleh sebagian masyarakat Indonesia untuk mengobati beberapa penyakit. Seperti di daerah Sunda (Jawa Barat) buah sirsak yang muda banyak digunakan untuk obat penurun tekanan darah tinggi dan di Aceh buah sirsak digunakan sebagai obat hepatitis dan daunnya sebagai obat batuk (Lundeen and Roberson, 1995). Selain itu menurut Lavella, tanaman ini juga digunakan untuk obat ambeien, mencret pada bayi, bisul, sakit pinggang, anyanganyangan dan sakit kandung air seni, tanaman ini juga bersifat antibakteri, antiparasit, antipasmodik, antikanker, insektisida, hipotensif, mengobati sakit perut dan mampu mengeluarkan racun.

Salah satu kandungan kimia sirsak yang berperan penting untuk obat adalah flavonoid. Flavonoid merupakan sa lah satu metabolit sekunder dan keberadaannya pada daun tanaman dipengaruhi oleh proses fotosintesis sehingga daun muda belum terlalu banyak mengandung flavonoid. Flavonoid merupakan senyawa bahan alam dari golongan fenolik. (Pitman, 1984).

Plak gigi merupakan salah satu masalah dalamkesehatan gigi dan mulut, yang merupakan deposit lunak yang melekat erat pada gigi, terdiri atas mikroorganismeyang berkembang biak jika seseorang melalaikan kebersihan gigi dan mulutnya. ${ }^{5}$ Salah satu bakteri utama penyebab terjadinya plak padagigi adalah Streptococcus mutans. Bakteri ini merupakan organisme paling kariogenikdi rongga mulut karena kemampuan asidurik dan asidogeniknya tinggi. (Nimah, Ma'ruf, \& Trianto, 2012).

Salah satu alternatif untuk dapat mengendalikan plak adalah dengan menggunakan bahan-bahan yang berasal dari alam seperti yang bersifat antibakteri untuk mengendalikan perubahan flora normal rongga mulut, salah satu bahan alam yang dapat digunakan adalah polifenol yang terkandung dalam beberapa tanaman, salah satunya adalah dalam daun sirsak (Alali, Liu, Mc-Laughlin, 1999).

Berdasarkan manfaat dari daun sirsak tersebut, maka tujuan penelitian ini adalah isolasi dan identifikasi senyawa pada fraksi paling aktif ekstrak daun sirsak (Annona muricata L.), terhadap daya hambatnya pertumbuhan bakteri Streptococcus mutans ATCC 31987.

\section{BAHANDAN METODE}

Penelitian ini merupakan penelitian eksperimental laboratoris dengan rancangan penelitian posttestonly control group design. Penelitianini dilaksanakan pada bulan Februari- Juli2017. Subjek dari penelitian ini adalah bakteri Streptococcus mutans ATCC 39187. Variabel penelitian ini yaitu ekstrak etil asetat daun sirsak dan pertumbuhan Streptococcus mutans ATCC 39187.

Pembuatan ekstrak dilakukan di Laboratorium Farmasi STIKes Muhammadyah Pekalongan. Daun sirsak sebanyak $1000 \mathrm{~g}$ didapatkan dari B2P2TOOT (Balai Besar Penelitian dan Pengembangan Tanaman Obat dan Obat Tradisional) Tawamangu. Daun sirsak diekstraksi bertingkat dengan cara maserasi menggunakan beberapa pelarut ( $n$-heksan, etil asetat, etanol, dan air) secara berurutan, khusus untuk air dilakukan juga infusa. Semua serbuk direndam dalam pelarut selama \pm 24 jam secara berulang-ulang untuk masingmasing pelarut yang digunakan sampai diperoleh filtrat bening, kemudian disaring. Ekstrak $n$-heksan dipisahkan dari pelarutnya dengan rotary vacum evaporator sehingga diperoleh ekstrak kental $n$-heksan. Residu dimaserasi dengan pelarut etil asetat, diperoleh filtrat etil asetat, kemudian residunya dimaserasi dengan etanol didapat filtrat etanol dan residunya di maserasi dengan air, didapat filtrat Air. Infusa menggunakan pelarut air juga dilakukan pada simplisia langsung. Selanjutnya dilakukan pemekatan hasil 
ekstrasi menggunakan rotary evavorator.

Bakteri yang digunakan dalam penelitian ini adalah Streptococcus mutans ATCC 31987 yang berasal dari Fakultas Kedokteran Universitas Indonesia. Streptococcus mutans ATCC 31987 kemudian dilakukan peremajaan selama $1 \times 24$ jam dengan suhu $37^{0} \mathrm{C}$ pada agar miring. Selanjutnyadibuat beberapa varian konsentrasi dan diuji dengan metode difusi cakram. Pengukuran zona hambat ekstrak daun sirsak dilakukan pada 3 cawan petri dengan tiga perlakuan yang berbeda yaitu kelompok ekstrak, kontrol positif amoxicillin, dan kontrol negatif etil asetat.

Metode yang digunakan ialah metode difusi lempeng agar (Kirby-Bauer) yang merupakan metode uji diameter daya hambat langsung. Agar NA dibuat sebanyak 3 cawan petri pada gabungan Fraksi F.7.1 sampai gabungan Fraksi F.7.4 hasil dari fraksinasi ekstrak etil asetat. Streptococcus mutans ATCC 31987 disebar secara merata dengan menggunakan swab pada permukaan agar NA. Kertas cakram diberi ekstrak daun sirsak dengan konsentrasi $40 \%, 20 \%$, $10 \%$ dan $5 \%$ dan dibuat juga untuk kontrol positif dan kontrol negatif. Cakram tersebut lalu diletakkan di media agar yang sudah dioleskan bakteri Streptococcus mutans ATCC 31987, selanjutnyadi inkubasi selama 24 jam pada suhu $37^{0}$.

Zona hambat yang terbentuk disekitar kertas cakram diukur diameter vertikal dan diameter horizontal dengan satuan millimeter $(\mathrm{mm})$ menggunakan jangka sorong dan diukur dengan rumus:

Diameter zona bening - Diameter disk = diameter daya hambat

Data yang digunakan dalam penelitian ini dihitung secara manual dan data yang sudah diolah disajikan dalam bentuk tabel, gambar, dan tulisan.

\section{HASIL PENELITIAN}

1. Ekstraksi Daun Sirsak

Masing-masing tahap ekstraksi dilakukan hingga pelarut yang digunakan untuk tiap ekstraksi berwarna bening. Hal tersebut menandakan bahwa senyawa telah terekstraksi seluruhnya. Hasil maserasi disaring dan filtrat yang diperoleh kemudian diuapkan pelarutnya dengan rotary evaporator pada suhu $50^{\circ}$. $60^{\circ} \mathrm{C}$ dan untuk ekstrak air diuapkan pada waterbath pada suhu $100^{\circ} \mathrm{C}$, sehingga diperoleh ekstrak kental.

Tabel 1. Hasil Ekstraksi dan Rendemen Ekstrak Daun Sirsak

\begin{tabular}{lcc}
\hline $\begin{array}{c}\text { Nama } \\
\text { Ekstrak }\end{array}$ & $\begin{array}{c}\text { Bobot } \\
\text { Ekstrak } \\
\mathbf{( g )}\end{array}$ & $\begin{array}{c}\text { Rendemen } \\
\text { Ekstrak } \\
\mathbf{( \% )}\end{array}$ \\
\hline $\begin{array}{l}\text { Ekstrak } \\
\text { N-heksan }\end{array}$ & 144,01 & 14,41 \\
\hline $\begin{array}{l}\text { Ekstrak } \\
\text { Etil Asetat }\end{array}$ & 176,18 & 17,62 \\
\hline $\begin{array}{l}\text { Ekstrak } \\
\text { Etanol }\end{array}$ & 195,92 & 19,60 \\
\hline $\begin{array}{l}\text { Ekstrak } \\
\text { Air }\end{array}$ & 55,01 & 5,51 \\
\hline $\begin{array}{l}\text { Ekstrak } \\
\text { Air (Infus) }\end{array}$ & 164,01 & 16,41 \\
\hline
\end{tabular}

\section{Uji Aktivitas Antibakteri}

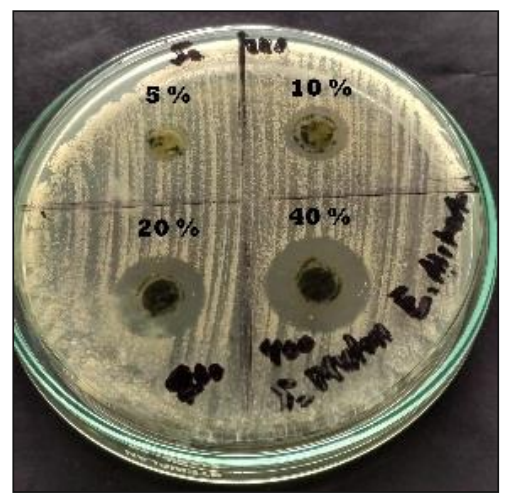

Gambar 1. Zona hambat yang terbentuk Pada media Nutrien Agar

Uji aktivitas antibakteri dilakukan pada semua ekstrak yang didapat. Cawan petri yang berisi media Nutrien Agar dan bakteri Streptococcus mutans ATCC 
31987 yang telah diberi perlakuan diambil dari dalam inkubator setelah diinkubasi selama 1×24 jam. Hasil menunjukan ekstrak etil asetat memiliki aktivitas paling besar yaitu $6,53 \mathrm{~mm}$ pada konsentrasi $10 \%$.

Zona hambat yang dihasilkan dari masing-masing perlakuan memiliki diameter yang berbeda-beda. Pengamatan dilakukan dengan cara mengukur diameter zona bening yang terbentuk disekitar kertas cakram. Pengujian dilakukan pada setiap fraksi hasil dari kromatografi kolom. Hasil pengukuran diameter zona hambat yang terbentuk dapat dilihat padaTabel berikut :

Tabel 2. Hasil Pengujian Gabungan Fraksi 1 sampai 4

\begin{tabular}{ccccc}
\hline \multirow{2}{*}{ Perlakuan } & \multicolumn{4}{c}{ Rata2 Diameter } \\
\cline { 2 - 5 } & Gab. & Gab. & Gab. & Gab. \\
& F.7.1 & F.7.2 & F.7.3 & F.7.4 \\
\hline $5 \%$ & 1 & 0,73 & 1,53 & 2 \\
\hline $10 \%$ & 1,20 & 0,83 & 1,67 & 2,10 \\
\hline $20 \%$ & 1,57 & 1,03 & 2 & 2,27 \\
\hline $40 \%$ & 1,67 & 1,07 & 2,27 & 2,47 \\
\hline Kontrol (-) & 0 & 0 & 0 & 0 \\
\hline Kontrol (+) & 6,90 & 6,90 & 6,90 & 6,90 \\
\hline
\end{tabular}

\section{Fraksinasi}

Fraksinasi dilakukan pada ekstrak etil asetat. Tiap fraksi yang telah dipisahkan menggunakan kromatografi kolom dilihat profil KLT (Kromatografi Lapis Tipis), untuk dilakukan penggabungan dan kembali dilakukan uji antibakteri. Hal ini dilakukan sampai didapat isolat yang mempunyai satu noda pada KLT untuk selanjutnya dilakukan identifikasi senyawa.

Pengeringan dilakukan pada sub. Fraksi F.7.IV, hasil dari kromatografi kolom II, gabungan fraksi 7.Isolat yang didapat dengan berat $2 \mathrm{mg}$ berbentuk cair seperti minyak dan berwarna kuning kehijauan. Hal ini dilakukan karena zona bening terbesar, terdapat pada fraksi ini.

\section{Indentifikasi Senyawa Kimia}

Isolat dilakukan identifikasi senyawa menggunakan LC-MS dan gugus fungsi dengan FT-IR di Laboratorium terpadu Fakultas MIPA Universitas Negeri Sebelas Maret Surakarta Jawa Tengah.

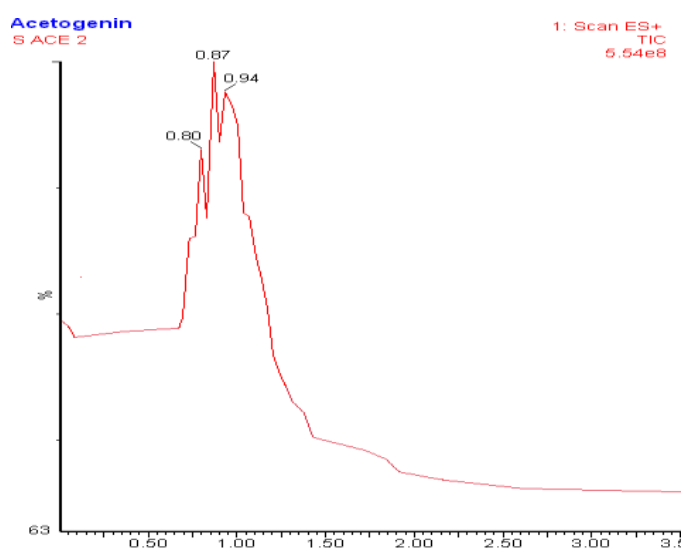

Gambar 2. Hasil LC-MS isolat Fraksi F.7.4

Hasil puncak dari kromatografi cair kinerja tinggi dan spektroskopi massa menujukan ada tiga senyawa yaitu pada waktu retensi 0,80, 0,87 dan 0,94. Diduga merupakan senyawa- senyawa isomer, hal ini dapat dilihat dengan berdekatannya waktu retensi pada ketiga senyawa.

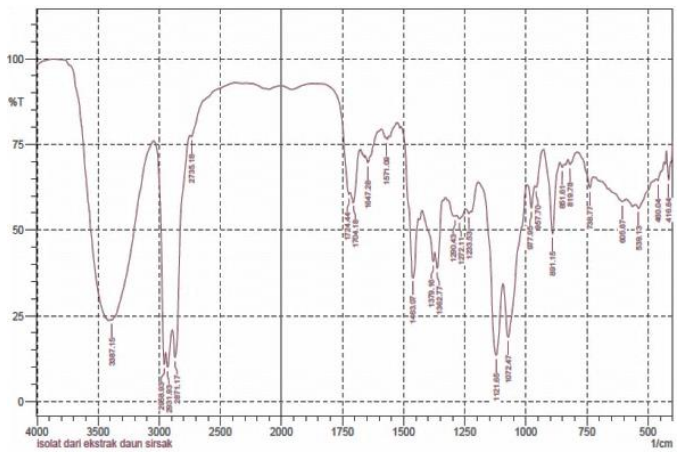

Gambar 3. Hasil LC-MS isolat Fraksi F.7.4

Analisis senyawa dapat dilakukan dengan membandingkan gugus fungsi pada FT-IR dan pola fragmentasi senyawa pada sampel dan senyawa-senyawa yang terdapat pada daun sirsak yang sudah teridentifikasi, salah satunya yaitu senyawa acetogenin. 
Puncak senyawa I memiliki waktu retensi 0,80 menit, terdapat puncak ion molekul pada $\mathrm{M}^{+} 612\left(\mathrm{C}_{35} \mathrm{H}_{64} \mathrm{O}_{8}\right)$ yang memiliki kemiripan dengan senyawa annonpentocin $\mathrm{C}$.

Tabel 3. Spektrum IR Senyawa Sub. Fraksi F.7.4 dan annonpentocin C

\begin{tabular}{ccc}
\hline $\begin{array}{c}\text { Senyawa } \\
\text { Hasil } \\
\text { Isolasi }\end{array}$ & $\begin{array}{c}\text { Anonpentocin } \\
\mathbf{C}^{7}\end{array}$ & $\begin{array}{c}\text { Gugus } \\
\text { Fungsi }^{8}\end{array}$ \\
\hline $3387 \mathrm{~cm}^{-1}$ & $3378 \mathrm{~cm}^{-1}$ & $\begin{array}{c}\text { OH (Intra } \\
\text { hidrogen bond) }\end{array}$ \\
\hline $2931 \mathrm{~cm}^{-1}$ & $2925 \mathrm{~cm}^{-1}$ & $\mathrm{C}-\mathrm{H}$ alkene \\
\hline $2871 \mathrm{~cm}^{-1}$ & $2853 \mathrm{~cm}^{-1}$ & $\mathrm{C}-\mathrm{H}$ alkene \\
\hline $1724 \mathrm{~cm}^{-1}$ & $1750 \mathrm{~cm}^{-1}$ & $=\mathrm{O}$ Ketone \\
\hline $1463 \mathrm{~cm}^{-1}$ & $1458 \mathrm{~cm}^{-1}$ & $-\mathrm{CH}_{2-}$ \\
\hline
\end{tabular}

Data serapan IR memberikan pita serapan melebar dan kuat pada bilangan gelombang $3387 \mathrm{~cm}^{-1}$, mengidentifikasikan adanya gugus $\mathrm{OH}$. Selanjutnya pada bilangan $2931 \quad \mathrm{~cm}^{-1} \quad$ yang mengidentifikasikan adanya gugus $\mathrm{C}-\mathrm{H}$ siklik jenuh yang diperkuat dengan munculnya serapan intensitas sedang pada $1463 \mathrm{~cm}^{-1}$ yang diduga milik $-\mathrm{CH}_{2}$ Kemudian terdapat serapan dengan intensitas sedang pada bilangan $1724 \mathrm{~cm}^{-1}$ dari gugus keton.

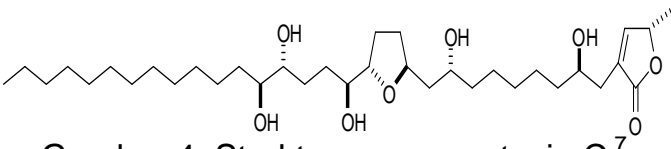

Gambar 4. Struktur annonpentocin $\mathrm{C}^{7}$

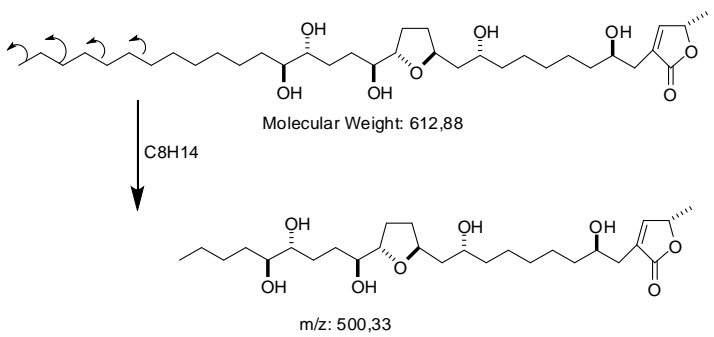

Gambar 5. Pola Fragmentasi senyawa I

Fragmentasi senyawa hasil isolasi memiliki perbedaan yang sangat kecil dengan fragmentasi senyawa annonpentocin C. Hal ini dapat disimpulkan bahwa senyawa I, diduga merupakan senyawa annonpentocin C. Dan berikut ini kemungkinan pola fragmentasi dari senyawa I.

Senyawa I mengalami fragmentasi dengan melepaskan gugus $\mathrm{CH}_{8} \mathrm{H}_{14}$ menghasilkan fragmen dengan $\mathrm{m} / \mathrm{z} 500,33$ membentuk struktur denganfragmen $\mathrm{m} / \mathrm{z}$ 500, $33\left(\mathrm{C}_{29} \mathrm{H}_{48} \mathrm{O}_{7}\right)$.

Puncak senyawa II memiliki waktu retensi 0,868 menit, terdapat puncak ion molekul pada $\mathrm{M}^{+} 612\left(\mathrm{C}_{35} \mathrm{H}_{64} \mathrm{O}_{8}\right)$ yang memiliki kemiripan dengan senyawa annopentocin B.

Tabel 4. Spektrum IR Senyawa Sub. Fraksi F.7.4 dan Annopentocin B

\begin{tabular}{ccc}
\hline $\begin{array}{c}\text { Senyawa } \\
\text { Hasil } \\
\text { Isolasi }\end{array}$ & $\begin{array}{c}\text { Annopentocin } \\
\mathbf{B}^{7}\end{array}$ & $\begin{array}{c}\text { Gugus } \\
\text { Fungsi }\end{array}$ \\
\hline $3387 \mathrm{~cm}^{-1}$ & $3400 \mathrm{~cm}^{-1}$ & $\begin{array}{c}\text { OH (Intra } \\
\text { hidrogen bond) }\end{array}$ \\
\hline $2931 \mathrm{~cm}^{-1}$ & $2935 \mathrm{~cm}^{-1}$ & $\mathrm{C}-\mathrm{H}$ alkene \\
\hline $2871 \mathrm{~cm}^{-1}$ & $2845 \mathrm{~cm}^{-1}$ & $\mathrm{C}-\mathrm{H}$ alkene \\
\hline $1724 \mathrm{~cm}^{-1}$ & $1749 \mathrm{~cm}^{-1}$ & $=\mathrm{O}$ Ketone \\
\hline $1463 \mathrm{~cm}^{-1}$ & $1463 \mathrm{~cm}^{-1}$ & $-\mathrm{CH}_{2-}$ \\
\hline
\end{tabular}

Data serapan IR memberikan pita serapan melebar dan kuat pada bilangan gelombang $3387 \mathrm{~cm}^{-1}$, mengidentifikasikan adanya gugus $\mathrm{OH}$. Selanjutnya pada bilangan $2931 \mathrm{~cm}^{-1} 2931 \mathrm{~cm}^{-1}$ yang mengidentifikasikan adanya gugus $\mathrm{C}-\mathrm{H}$ siklik jenuh yang diperkuat dengan munculnya serapan intensitas sedang pada $1463 \mathrm{~cm}^{-1}$ yang diduga milik $-\mathrm{CH}_{2}$. Kemudian terdapat juga serapan dengan intensitas sedang pada bilangan $1724 \mathrm{~cm}^{-1}$ yang diduga merupakan gugus keton.

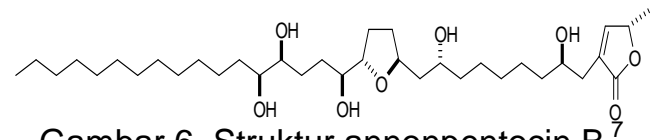

Fragmentasi senyawa hasil isolasi memiliki perbedaan yang sangat kecil dengan fragmentasi senyawa Annopentocin B. Dengan ini dapat disimpulkan bahwa senyawa II, diduga merupakan senyawa Annopentocin B. 


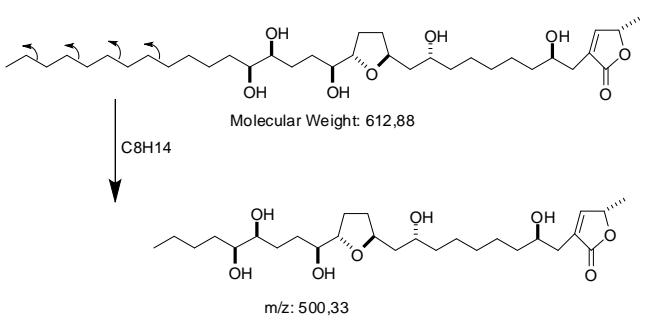

Gambar 7. Pola Fragmentasi senyawa II

Puncak senyawa III memiliki waktu retensi 0,94 menit, terdapat puncak ion molekul pada $\mathrm{M}^{+} 612\left(\mathrm{C}_{35} \mathrm{H}_{64} \mathrm{O}_{8}\right)$ yang memiliki kemiripan dengan senyawa annomuricin-D-one.

Tabel 5. Spektrum IR Senyawa Sub. Fraksi F.7.IV dan annomuricin-D-one

\begin{tabular}{ccc}
\hline $\begin{array}{c}\text { Senyawa } \\
\text { Hasil } \\
\text { Isolasi }\end{array}$ & $\begin{array}{c}\text { annomuricin- } \\
\text { D-one }\end{array}$ & $\begin{array}{c}\text { Gugus } \\
\text { Fungs }\end{array}$ \\
\hline $3387 \mathrm{~cm}^{-1}$ & $3425 \mathrm{~cm}^{-1}$ & $\begin{array}{c}\text { OH }(\text { Intra } \\
\text { hidrogen bond })\end{array}$ \\
\hline $2931 \mathrm{~cm}^{-1}$ & $2925 \mathrm{~cm}^{-1}$ & C-H alkene \\
\hline $2871 \mathrm{~cm}^{-1}$ & $2835 \mathrm{~cm}^{-1}$ & $\mathrm{C}-\mathrm{H}$ alkene \\
\hline $1724 \mathrm{~cm}^{-1}$ & $1765 \mathrm{~cm}^{-1}$ & $=\mathrm{O}$ Ketone \\
\hline $1704 \mathrm{~cm}^{-1}$ & $1715 \mathrm{~cm}^{-1}$ & $=\mathrm{O}$ Ketone \\
\hline $1463 \mathrm{~cm}^{-1}$ & $1455 \mathrm{~cm}^{-1}$ & $-\mathrm{CH}_{2-}^{-}$ \\
\hline $1367 \mathrm{~cm}^{-1}$ & $1362 \mathrm{~cm}^{-1}$ & $\mathrm{CH}\left(\mathrm{CH}_{3}\right)_{3}$ \\
\hline
\end{tabular}

Data serapan IR memberikan pita serapan melebar dan kuat pada bilangan gelombang $3387 \mathrm{~cm}^{-1}$, mengidentifikasikan adanya gugus $\mathrm{OH}$. Selanjutnya pada bilangan $2931 \mathrm{~cm}^{-1}$ dan $2871 \mathrm{~cm}^{-1}$ yang mengidentifikasikan adanya gugus $\mathrm{C}-\mathrm{H}$ siklik jenuh yang diperkuat dengan munculnya serapan intensitas sedang pada $1463 \mathrm{~cm}^{-1}$ yang diduga milik $-\mathrm{CH}_{2}-$. Kemudian terdapat serapan dengan intensitas sedang pada bilangan $1724 \mathrm{~cm}^{-1}$ dan $1704 \mathrm{~cm}^{-1}$ yang berasal dari gugus keton dan adanya serapan pada $1362 \mathrm{~cm}^{-1}$ menandakan adanya gugus alkena tertbutyl.

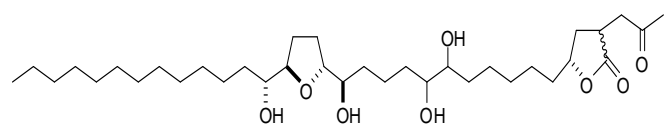

Gambar 8. Struktur Annomuricin-D-One ${ }^{7}$
Senyawa III mengalami fragmentasi dengan melepaskan gugus $\mathrm{C}_{2} \mathrm{H}_{4}$ menghasilkan fragmen dengan $\mathrm{m} / \mathrm{z} 584$, kemudian melepaskan lagi $\mathrm{C}_{2} \mathrm{H}_{4}$ dan membentuk fragmen dengan $\mathrm{m} / \mathrm{z} 556$ dan selanjutnya melepaskan $\mathrm{CH}_{2}$ membentuk struktur dengan fragmen $\mathrm{m} / \mathrm{z} 542,38$ $\left(\mathrm{C}_{30} \mathrm{H}_{54} \mathrm{O}_{8}\right)$.

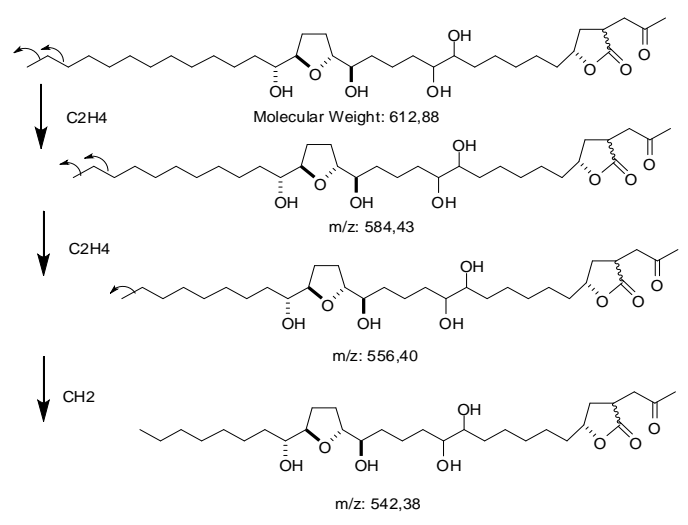

Gambar 9. Pola Fragmentasi senyawa III

\section{KESIMPULAN}

Isolat pada Sub Fraksi F.7.IV dari ekstrak daun sirsak memiliki aktivitas antibakteri melalui daya hambat pertumbuhan pada bakteri Streptococcus mutans ATCC 31987 pada konsentrasi $40 \%, 20 \%, 10 \%$ dan $5 \%$ dengan kategori tidak aktif, Analisis data dan identifikasi senyawa dilakukan dengan LCMS dan FTIR, terdapat campuran 3 senyawa yaitu; Annopentocin C, Annopentocin B dan Annomuricin D-one.

\section{DAFTAR PUSTAKA}

Alali F.Q, Liu X, McLaughlin J.L., (1999). Annonaceous Acetogenins; Recent Progres. Department of Medicinal Chemistry and Molecular Pharmacology, School of Pharmacy and Pharmacal SciencesPurdue University, West Lafayette, Indiana 47907. 1998. Journal. Nat. Prod.

De jong, M.F., (1999). Progessive and nonprogressive atrophic rhinitis. Disease of Swine. 8th ed. Lowa State University Press. Aress. Ames. Lowa, USA. 
Jawetz, E., Melnick, J., \& Adelberg, E., (2005). Mikrobiologi Kedokteran, Diterjemahkan oleh Mudihardi. E., Kuntaman, Wasito, EB, Mertaniasih, NM, Harsono, S., Alimsardjono, L, Edisi XXII. Salemba Medika. Jakarta.

Lavelle C.L.B. Applied oral physiology. 2nd ed. London: Wright. p. 96-7.

Lundeen T.F., Roberson T.M. (1995).

Cariology: the lesion, etiology,

prevention, and control. In: $\mathrm{CM}$

Sturdevant, TM Roberson, $\mathrm{HO}$

Heymann, JR Sturdevant, editors. The

art and science of operativedentistry. 3th ed. St Louis: Mosby-Year Book Inc.
Mulja M dan Suharman, (1995). Analisis Instrumental. Airlangga University Press. Surabaya.

Nimah, S., Ma'ruf, W. F., \& Trianto, A., (2012). Uji Bioaktifitas ekstrak Terimpang Pasir (holothuria scabra) terhadap bakteri Pseudemonas aeruginosa dan Bacillus cereus. Jurnal Pengolahan dan Bioteknologi Hasil Perikanan, I.

Pitman, M. (1984). Genus Bordetella. In Krieg. N.R. And J.G. Holt (Eds). Bergey's Manual of Determinatifve Bacteriology Williams and Wilkins. Baltimor and London. 
